\title{
The Application of Micro Lesson in College Chinese Teaching
}

\section{Zhang Guangcai}

Nanchang Institute of Science \&Technology, Nanchang 330108,China

\begin{abstract}
Keywords: Curriculum reform, Micro lesson, College language.
\end{abstract}
\begin{abstract}
With the continuous development of the two kinds of the political and economic system reform, the production mode and life style of our country have changed greatly, and the school education system need to further reform. An important way of curriculum is to achieve the education purpose, and the most important basis is the organization educational activities and the education thought as the carrier. For the reform of the education system, the first is to achieve the curriculum reform. The implementation of the new curriculum reform cannot only rely on the reform of the education system, and teachers' teaching methods need to change, so that students can improve the desire of learning and the quality of classroom teaching. Based on the requirements of college students' college language courses, this paper takes video teaching as the main carrier to carry out the application of micro teaching in college language teaching, this method not only can effectively improve the students' learning level, but also can promote teachers' teaching level.
\end{abstract}

\section{Introduction}

With the continuous development of the times, information technology and multimedia technology are also in constant progress, people's production and life style have changed a lot. The rapid development of internet technology promotes the application of multimedia teaching, so the use of modern educational media carries out education and teaching activities, it not only can active classroom atmosphere, but also can help to break through teaching difficulties, greatly improving the quality of teaching [1-3]. Micro teaching is as a new product of the new era, the micro lesson will continue to develop and form a new teaching system after a large number of mobile terminal devices are widely spread.

\section{Overview of Micro Lesson}

The internet era rises up the micro blog, micro channel, micro film, micro fiction, micro purchase, micro marketing and so on a series of the micro era product, surging the micro lesson under the big background $[4,5]$. Micro teaching takes the short video as the main carrier in accordance with the requirements of the education ministry new curriculum reform, and the video time is generally not more than 10 minutes. The micro teaching purpose is very clear, curriculum content is essence and not much, it mainly records that teachers focus on a difficult factor knowledge points or the process of teaching and learning activities carried out by a link [6]. The schematic diagram of the micro lesson is shown in Figure 1.

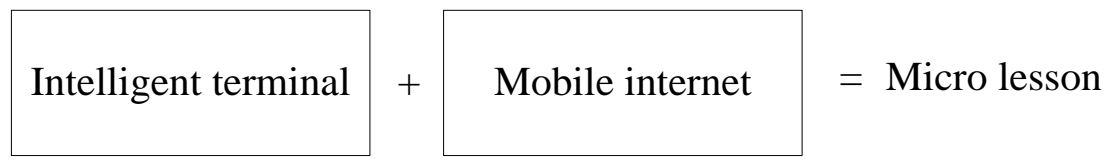

Fig. 1 The schematic diagram of the micro lesson

As shown in Figure 1, the micro lesson is the product of the combination of intelligent terminal and mobile internet. The micro lesson focus lies in the classroom teaching video, the video is generally a fragment or an example of knowledge, but also needs a series of related materials, exercises, tests, related information and teaching feedback, these around a point of teaching knowledge together to create a clearly theme and purpose small classroom, and come down in one continuous line and traditional classroom, and there are its unique place [7,8]. In fact, the micro 
lesson is a kind of a new teaching mode based on the development of traditional classroom teaching model. The typical characteristics of the micro class are shown in Figure 2.

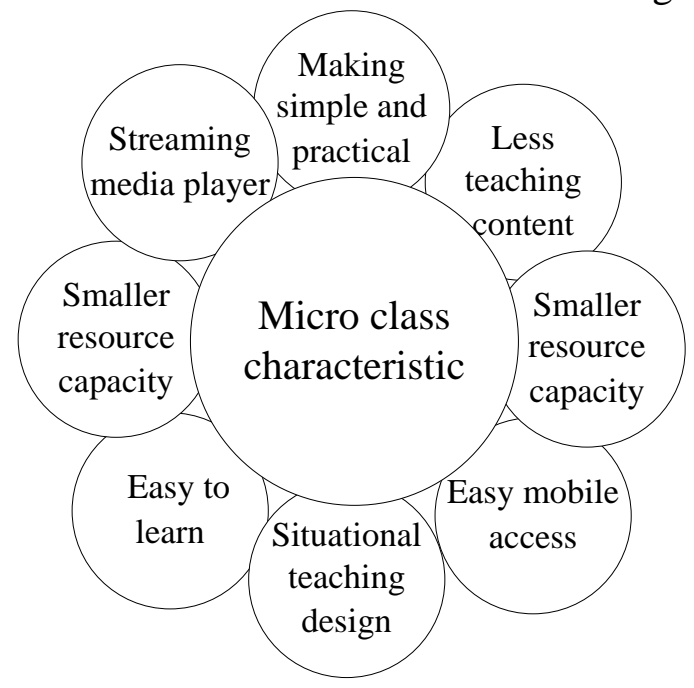

Fig.2 The typical characteristics of micro lesson

As shown in Figure 2, micro class not only makes the ideal of the teachers to teach students in accordance with their aptitude as possible, but also let students moving debris, personalized learning to become a reality. The micro teaching includes short teaching time, less teaching content, smaller resource capacity, the formation of resource situational teaching design, theme outstanding, content specific, simple results, variety communication, feedback timely, targeted strong, easy to students autonomous learning, easy to access mobile terminal and other characteristics.

\section{The Application of Micro Teaching Method in College Chinese Teaching}

College language is a basic course of college language education, it is not only a kind of communication tool, but also is a window for understanding human civilization and the national development window [9-11]. The college language curriculum has been attached great importance by students and teachers, and the application and promotion of micro teaching in language teaching will also be welcomed. The application of micro teaching in college language teaching is shown in Figure 3 .

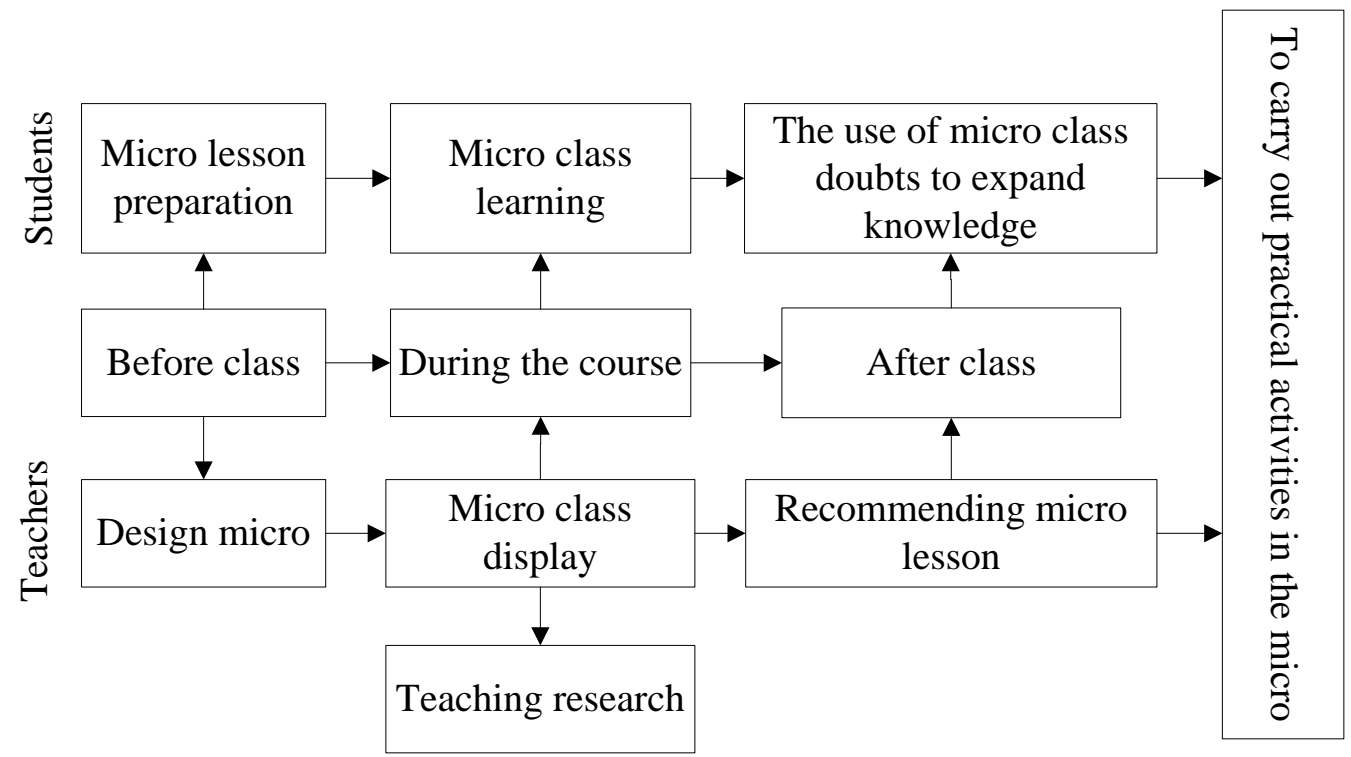

Fig. 3 The application of micro teaching in college language teaching

Micro teaching can improve the students learning ability. College students have more spare time during the university, they usually emphasize on self - oriented and focus on students' self-learning, students can set up their own learning plan, complete self-supervision and self-adjustment through their own situation, so as to improve their learning ability. The knowledge 
point of the micro lesson is relatively simple, content refined, the simple and easy to understand, especially suitable for autonomous learning [12]. Using the form of micro class learning, college students generally take the preview before class, learning in class and consolidating and expanding the knowledge way after class. Preview before class is that students can have a good understanding knowledge according to micro lesson, and they are easy to grasp the key points during the class; learning in class is that students can focus on solving the difficult understanding problem according to the preview control; consolidating and expanding the knowledge after class can help students learning for their interest content, effectively broadening their knowledge, expanding their own development space and supplementing the range of classroom narrow knowledge.

Micro lesson can make the classroom content diversity. The application of micro teaching in college teaching can realize the sharing of teaching resources. Micro lesson content is generally relatively brief, and its production will be easier [13]. Therefore, people need a very good use of micro lesson in the course of college language, combined with the basic knowledge and the requirement of expanding knowledge, people can maximize the students' learning interest by enlarging the knowledge points. At the same time, enriching the college language class knowledge can reduce the single nature of the classroom contents, to increase the diversity of college Chinese classroom contents.

Micro teaching can promote the communication of the University language teaching and research activities. Compared with the traditional teaching way, the use of micro class teaching can effectively solve the teacher around subtle issues, specific problems or a theme in daily teaching and research process [14]. With the regional network study platform, teachers make full use of micro classes, teaching design, a variety of teaching resources and technical means, to carry out a comprehensive multi-level, diversified, multi subject mutual discussion, interaction and achievement sharing, and then to further deepen the teacher's understanding on a certain knowledge point, which can improve teachers' professional level and effectively promote the exchange of university language education research activities.

\section{Application of Micro Teaching Mode in College Chinese Teaching}

The application mode of micro teaching in college language teaching mainly has three kinds of self-restraint, brought and cooperation. Homemade is that teachers themselves in class make micro lesson video according to the need to explain the knowledge, the micro teaching should be produced a good before starting, and then be applied in teaching; brought mainly collect more successful micro lesson video on the internet collect, or funded by the school buy a good commercial resources [15]; the cooperation is that organized by the education ministry has a purpose and planned to contact some high level university development at all levels of the university language micro class, to establish sound micro teaching resource library, and then to provide the use of schools and organize a high level of teaching activities in cooperation, the greatest degree shows the value of micro class.

The content of university language course is generally not much, the micro lesson is mainly aimed at a certain knowledge point for teaching design. A university language curriculum goes through cooperation way, and micro lesson can be more easily produced practical strong and high teaching quality by a team. Through these teaching resources, classroom teachers can better carry out the teaching work, to improve teaching quality and efficiency.

\section{The Characteristics of Micro teaching in College Chinese Teaching}

There is important practical significance for the combination of micro and college language courses. The application of micro teaching in college language teaching mainly has two aspects: one makes the university language teaching more standardized, and another can effectively expand the university language courses.

Micro courses make the university language teaching more standardized. The development of university language teaching content is relatively strong, and the expansion of knowledge is very rich. The knowledge points in teaching carries out the development, it is easy to deviate from the 
norm, especially the university language teachers [16]. Different teachers will expand the knowledge points of different levels in the same text and the same content because of their personal experience and personality differences. Micro lesson just can effectively solve this kind of defect. Micro lesson teaching time is short, and it is generally only a few minutes, teachers need to be clear about the need to teach knowledge points during this period, so that students can understand the core content of knowledge points. As a result, teachers must be concise, careful analysis knowledge, regulate the curriculum content and reduce the possibility from the teaching norms.

Micro teaching can effectively expand the university language course. For college students, the most important is extra-curricular autonomous learning. The teacher in the classroom takes guide the main, students need to carry out the knowledge finishing, consolidation and expansion after class, which are the typical teaching methods of college language course. However, in the university stage, the students in the course of learning often encounter more difficulties in depth. In the exchange of problems, the students because the equality of knowledge, it is difficult to get an effective solution, especially the practice or experience in the teacher's class teaching practice, teachers are generally difficult to detect, and students' professional courses are more, the task is arduous, so that they cannot have more time in the language courses to carry on the discussion. The teacher also because their own scientific research task, it is difficult for students to carry out effective counseling.

College students need to have a higher level of language, they need to learn the knowledge in the course of the supplementary and expansion after class, because the accumulation of extra-curricular knowledge has a very important significance on college language learning. Through the strong pertinence, the micro lesson completes the show of the teaching content in its unique way, and the students carry out the relevant knowledge point learning after class. Because the electronic resources of the micro lesson is rich, the students can use the form of micro class learning for the knowledge point of the expansion, it can guide students' autonomous learning, stimulating students' learning interest and improving students' autonomous learning ability; the students can take the way of research, encouraging students to actively explore learning and to discuss as a platform, greatly stimulating students' creative thinking, to improve students' language level.

\section{Summary}

With the increasing popularity of the internet and the development of video compression and transmission technology, wireless networks is the growing popularity, the internet has entered the micro era, and then micro blog, micro channel and micro video came into being at the unimaginable speed quickly popular. This paper studies the application of micro teaching in college language teaching, and realizes the positive role of college language curriculum reform. At the same time, people also understands that the micro teaching has important application value in college language teaching, so The rapid development of the micro course is in accordance with the requirements of the times, which can effectively improve the students' autonomous learning ability and promote the development of teachers' teaching practice activities.

\section{References}

[1] X.R. Zhao. The application of the micro lesson in Yinchuan based on primary school Chinese teaching. Ningxia University, 2014: 1-7.

[2] Y.Q.Zhang. Application of micro class in primary school language teaching. China school education, 2015(30): 9-12.

[3] S.L. Zhang. Setting characteristics curriculum, starting from the student needs, to ensure the construction of characteristic schools as objective. New courses, 2014(4):137-139.

[4] G.J. Gao. To create a new class in micro class -- analysis on the efficient information technology based on the micro class concept. Education, 2014(12): 28-30. 
[5] C.X. Fan. Application and value exploration of the micro class in Chinese language teaching. Middle school Chinese, 2014(33): 36-37.

[6] H.H. Shen. To improve the efficiency of mathematics learning through the micro. College entrance exam, 2014(12): 63-64.

[7] G. Yu. The application of the micro class in the in higher vocational oral English teaching. Examination weekly, 2014(98): 87-88.

[8] L.J. Yu. The design and application of Micro class in junior middle school science curriculum - taking the internal energy of object teaching as example. Primary and middle school teaching, 2015(5): 47-49.

[9] C.G. Zuo. The application of micro teaching in higher mathematic information teaching. Journal of Suzhou Education Institute, 2014(6): 224-225.

[10] Z.Q. Ma. Digital interpretation, booster teaching -- Practice and reflection on micro teaching in junior high school English teaching. English teachers, 2015(3): 154-157.

[11] X. Zhao, Z.G. Li. The application and development trend of micro teaching in college English teaching. Journal of Huaibei Vocational and Technical College, 2015(3): 44-45.

[12] S.S. Wu. he design and application of the micro class resources in primary Chinese literacy class. Shandong Normal University, 2015: 3-12.

[13] H.S. Li. The application of micro teaching in college physical education. Yunnan University, 2015: 1-8.

[14] L. Yang. Research on the higher education reform under the perspective of basic education curriculum reform. Shaanxi Normal University, 2013: 3-11.

[15] Y. Yang. The curriculum reform of middle school moral education under the background of knowledge economy. Commodity and quality, 2013(1): 256-258.

[16] X.Y. Yu. The analysis of micro class application limitations and its countermeasures in language reading teaching. Middle School Chinese, 2015(30): 6-7. 